\title{
The Corelation Between Work-Stress Level and Obesity Among Teacher
}

\author{
$* 1^{\text {st }}$ Nina Dwi Lestari \\ School of Nursing \\ Universitas Muhammadiyah \\ Yogyakarta \\ Yogyakarta, Indonesia \\ ninadwilestari240708@gmail.com
}

\author{
$2^{\text {nd }}$ Altori Samantha Evanov \\ Universitas Muhammadiyah \\ Yogyakarta \\ Yogyakarta, Indonesia \\ altori.samantha@yahoo.com
}

\begin{abstract}
The teacher is one of the aggregates of workers who have a high risk of work-stress due to many demands of work, duties, and responsibilities. Stress can support the occurrence of obesity caused by changes in behavior and metabolism. This study aimed to determine the relationship between stress and obesity in senior high school teachers. This is quantitative research with a descriptive correlation design. The subjects were 63 teachers at Muhammadiyah Senior High School 1 Salam, collected by the total sampling technique. The research instrument uses a job stress questionnaire developed by researchers who have tested CVI and validity and reliability. The statistical test used was the SpearmanRank test. The study results showed that most respondents were teachers of early adulthood (26-35) years old, male sex, with a long working period of more than three years. Most respondents are in moderate stress $($ mean $=31,13, \mathrm{SD}=4$, 75) with a healthy BMI category. The relationship between work stress and obesity in teachers is $p$ value $=0.157$. There was no significant relationship between work stress and obesity in teachers at Muhammadiyah Senior High School.
\end{abstract}

Keywords-Work-stress, teachers, obesity, occupational health.

\section{INTRODUCTION}

The teacher is an aggregate who is at risk of experiencing health problems due to work due to biological, environmental, and lifestyle risk factors. One of the health problems teachers often encounter is stress caused by the many demands of work and assignments. The more work demands faced, making teachers must be able to adapt well; when this is not achieved, it will cause job stress[1]. Stress is a condition where a person faces a compulsion (demands), obstacles (constraints), and opportunities (opportunities) associated with the results that are expected. However, it turns out that the results are uncertain and significant [2]. Stress caused by work is an expectation or an unsuitable work environment that causes physical and emotional disturbances [3]. Job stress is a depressing condition experienced by workers due to something incompatible with the individual. Stress is a health problem that occurs globally. As many as 385,000 people in the UK experience stress [4]. The 2013 Basic Health Research Data shows that $11.6 \%$ of Indonesia's population experiences emotional or emotional disturbances. The results of research related to stress among workers showed that as many as $41.4 \%$ of workers had heavy work stress, $56 \%$ experienced moderate work stress, and $2.85 \%$ experienced work stress in the low category [5].

Work stress is caused by several factors including (1) Role structure: workers who lack a role in decision making in organizations are at risk of experiencing work stress. (2) the part of individuals in organizations: reflecting how individuals can play according to the rules that exist in the organization. The inability to carry out the role will risk causing work stress. (3) career development, meaning that workers' uncertainty in developing a career will cause pressure on the workforce. (4) Poor work relations, involving that disharmony that occurs in the worker's environment, will cause pressure on workers to produce work stress. (5) Excessive workload and unsupportive environment, which means: workload and work environment that is not balanced with the work capacity of a worker, will risk causing work stress [6].

Stress experienced by workers will affect the behavior associated with efforts to reduce stress levels. One of them is a change in eating routine that is different from normal conditions. Someone who is in a state of stress will experience an increase in eating behavior and body metabolism. Stress can trigger the occurrence of obesityassociated with changes in eating behavior and metabolism [7].

Obesity is a condition of excess fat accumulation in the body that results in weight gain and endangers body health [8]. Obesity can be caused by a lack of physical activity, excessive consumption of food, and psychological factors such as stress [9]. The hormone cortisol is high in a person under pressure can affect the function and dist $r$ abuse fatty tissue that can lead to obesity such as central obesity [10]. Someone who is experiencing stress, his body will release the hormone cortisol. Increased levels of the hormone cortisol in the body will stimulate the body to release the hormones insulin, leptin and neuropeptide so that it can cause hunger; therefore, it will trigger someone's desire to eat [7].

Preliminary study results on teachers at Muhammadiyah Vocational Schools show that as many as 6 out of 10 teachers are obese with BMI above or equal to 30. Results of interviews with obese teachers say that they are often burdened with much work. The teacher claimed to feel stress often, especially when the number of work demands and 
workload is so massive that it creates pressure on him. Based on the phenomenon of work stress experienced by many workers, especially teachers, and it is possible to influence eating behavior, we need a study that aims to determine the relationship between work stress and obesity in teacher workers at SMK Muhammadiyah.

\section{METHOD}

This research method is quantitative descriptive with a correlation approach. Researchers aim to examine the relationship between work stress and the occurrence of obesity in teacher workers at SMK Muhammadiyah 1 Salam. This study uses a cross-sectional design with 63 teachers as respondents. Sampling is done by the Total Sampling method. This study's instrument was a job stress questionnaire developed by researchers that had been conducted to test the validity and Content Validity Index (CVI ) tests and the reliability test, which stated the work stress questionnaire used was valid and reliable. Tool for determining body mass index (BMI) using a weight scale and microtoise that has passed the calibration test. Analysis of data correlation test Spearman-Rank. This study was declared to have passed the research ethics review at the FKIK UMY Ethics Commission.

\section{RESULT}

\section{A. Respondent Characteristics}

Respondent characteristics in this study were used to determine respondents' general descriptions based on age, sex, and length of work (Table 1). Based on table 1, it is known that the majority of respondents in this study were male, with a total of 46 respondents (73\%). In this study, respondents were predominantly in early adulthood (26-35 years), with a total of 21 respondents $(33.3 \%)$. Most of the respondents in this study have long worked with 58 respondents $(92.1 \%)$.

TABLE I. DISTRIBUTION OF RESPONDENT CHARACTERISTICS FEBRUARY $2019(\mathrm{~N}=63)$

\begin{tabular}{|c|c|c|}
\hline Characteristics & $\begin{array}{l}\text { Frequency } \\
\text { (F) }\end{array}$ & Percentage (\%) \\
\hline \multicolumn{3}{|l|}{ Gender } \\
\hline Female & 17 & 27 \\
\hline Male & 46 & 73 \\
\hline \multicolumn{3}{|l|}{ Age } \\
\hline Late teens (17-25) & 3 & 4.8 \\
\hline Early Adults (26-35) & 21 & 33.3 \\
\hline Late Adult (36-45) & 20 & 31.7 \\
\hline Early Elderly (46-55) & 15 & 23.8 \\
\hline Late Elderly (56-65) & 4 & 6.3 \\
\hline \multicolumn{3}{|l|}{ Length of work } \\
\hline New $(<3)$ & 5 & 7.9 \\
\hline Old $(>3)$ & 58 & 92.1 \\
\hline Total & 63 & 100 \\
\hline
\end{tabular}

Source: Primary Data, 2019
Overview of Respondents' Work-stress Levels (Table 2) shows that most respondents experienced moderate stress in the category of 39 teachers $(79.4 \%)$ and at least experienced mild stress of 11 teachers (17.5\%). Table 2. Frequency Distribution of Respondents' Work-Stress Levels, February $2019(n=63)$

\section{B. Work-Stress Level}

Overview of Respondents' Work-stress Levels (Table 2) shows that most respondents experienced moderate stress in the category of 39 teachers $(79.4 \%)$ and at least experienced mild stress of 11 teachers $(17.5 \%)$.

TABLE II. FREQUENCY DISTRIBUTION OF RESPONDENTS' WORKSTRESS LEVELS, FEBRUARY $2019(\mathrm{~N}=63)$

\begin{tabular}{lcc}
\hline $\begin{array}{l}\text { Work-Stress } \\
\text { Category }\end{array}$ & Frequency & $\begin{array}{l}\text { Percentage } \\
\text { (\%) }\end{array}$ \\
\hline Mild & 11 & 17.5 \\
$\begin{array}{l}\text { Moderate } \\
\text { Severe }\end{array}$ & 39 & 79.4 \\
\multicolumn{1}{c}{ Total } & 13 & 20.6 \\
\hline
\end{tabular}

Source: Primary Data, 2019

\section{BMI Index}

This study uses manual stepping scales and height measurement tools that have been tested for calibration tools to calculate the value of the Body Mass Index (BMI) of the respondents. The results of weight and height values were calculated using the BMI formula. Based on table 3 obtained based on the characteristics of the IMT of teachers in SMK Muhammadiyah it was found that the majority of respondents IMT were normal as many as 34 respondents $(54.0 \%)$ and at least underweight were as many as 6 teachers $(9.5 \%)$

TABLE III. DISTRIBUTION OF IMT RESEARCH RESULTS RESPONDENTS OF SMK MUHAMMADIYAH 1 SALAM, FEBRUARY $2019(\mathrm{~N}=63)$

\begin{tabular}{lcc}
\hline \multicolumn{1}{c}{ BMI } & Frequency & Percentage (\%) \\
\hline Underweight & 6 & 9.5 \\
Normal & 34 & 54.0 \\
Overweight & 11 & 17.5 \\
Obesity & 12 & 19.0 \\
& & \\
\hline Total & 63 & 100.0
\end{tabular}

Source: Primary Data, 2019 


\section{Relationship between Work-stress and Obesity in the Teacher}

TABLE IV. RESUlTS OF THE SPEARMAN RANK STATISTICAL TEST FOR THE RELATIONSHIP BETWEEN WORK-STRESS AND OBESITY IN THE TEACHERS OF SMK MUHAMMADIYAH 1 SALAM, FEBRUARY $2019(\mathrm{~N}=63)$

\begin{tabular}{|c|c|c|c|c|c|c|c|}
\hline \multirow{2}{*}{$\begin{array}{l}\text { Work- } \\
\text { Stress } \\
\text { Level }\end{array}$} & \multicolumn{7}{|c|}{ BMI } \\
\hline & $\begin{array}{l}\text { Under } \\
\text { Weight }\end{array}$ & $\begin{array}{l}\text { Nor } \\
\text { mal }\end{array}$ & $\begin{array}{l}\text { Ove } \\
r \\
\text { Wei } \\
\text { ght }\end{array}$ & $\begin{array}{l}\text { Obesi } \\
\text { ty }\end{array}$ & Total & $\mathrm{R}$ & $\begin{array}{l}P \\
\text { valu } \\
\text { e }\end{array}$ \\
\hline \multirow[t]{4}{*}{ Mild } & 1 & 2 & 3 & 3 & 11 & & .157 \\
\hline & $16.7 \%$ & 11.8 & & & & .180 & \\
\hline & & $\%$ & 27.3 & 25.0 & 17.5 & & \\
\hline & & & $\%$ & $\%$ & $\%$ & & \\
\hline \multirow{3}{*}{$\begin{array}{l}\text { Moder } \\
\text { ate }\end{array}$} & 3 & 22 & 7 & 7 & 39 & & \\
\hline & $50.0 \%$ & 64.7 & 63.6 & 58.3 & 61.9 & & \\
\hline & & $\%$ & $\%$ & $\%$ & $\%$ & & \\
\hline \multirow[t]{3}{*}{ Severe } & 2 & 8 & 1 & 2 & 13 & & \\
\hline & $33.3 \%$ & 23.5 & 9.1 & 16.7 & 20.6 & & \\
\hline & & $\%$ & $\%$ & $\%$ & $\%$ & & \\
\hline \multirow[t]{3}{*}{ Total } & 6 & 34 & 11 & 12 & 63 & & \\
\hline & $100.0 \%$ & 100. & 100. & 100.0 & 100.0 & & \\
\hline & & $0 \%$ & $0 \%$ & $\%$ & $\%$ & & \\
\hline
\end{tabular}

\section{DISCUSSION}

This study shows that most of the teachers in this study were male $(73 \%)$. Teacher men are emotionally stable and have humor that makes him able to think more relaxed. The results of this study are supported by research conducted with respondents dominated by men [11]. The study results prove that someone with a masculine personality or man can better deal with stressors that come to him without emotional feelings and excessive levels of anxiety. This means that men are more able to control emotionally and have adaptive coping, which causes men not to be susceptible to stress. According to research, women have higher anxiety than men. Women are more likely to show stressful behavior. This is a way of emotional adjustment for women, in contrast to men who have self-confidence, so it is not easy to look anxious [12].

Differences in the stress response that occurs between males and females are associated with the activity of the hypothalamic-pituitary-adrenal (HPA) relating to the regulation of the hormone cortisol. The stress response was found to be higher in adult men than in adult women. This can affect a person's ability to carry out coping mechanisms against emerging stressors. The influence of hormones can cause women are more vulnerable and prone to stress [7]

The results showed that the respondents' age was dominated by early adulthood with a range (26-35 years) of $33.3 \%$. At the age of $26-35$, a person can still not control coping properly because, at this age range, he is still classified at a young age [7]. This study's results are in line with the review, which has the majority of respondents with age under $34(51.4 \%)$. The study explains that young workers are more likely to have coping mechanisms that are less adaptive than older workers. The younger the respondent's age, the more likely the individual is experiencing work stress [11].

The results showed that the respondents in this study mostly had years of service in the broad category of more than three years $(92.1 \%)$. The length of work determines how the ability of workers to adjust to the environment and coworkers. Workers with a long time working are still new, tend to be challenging to adapt. This is different from someone who already has long working experience. He can adapt well to his work environment and has more abilities that affect his work and himself. This study is in line with the results of previous survey that $51.4 \%$ of respondents have a long service life. Someone who has worked for a long time influences the level of work stress, one's experience at work influences this. Workers who have long years of service tend to have better understanding and ability than workers who have young years of service [13]. This experience and knowledge will help in overcoming problems or stressors that exist in efforts to prevent stress [11].

The results of the study in table 2 about the distribution of the effects of research on the level of work stress on teacher workers in SMK Muhammadiyah found that most of the stress levels of teachers in the moderate stress category were 39 teachers $(79.4 \%)$. The results of the analysis of the study that work regulations influence respondents who are experiencing stress because teachers are required to teach for 8-9 hours. This was proven based on the review of questionnaire items related to work stress. As many as 35 respondents answered they did not feel comfortable working with stringent regulations in their work environment. The result of previous study states that stress can be influenced by conditions of pressure or tension from being out of harmony with the work environment [14]. Every worker has the potential to experience work stress due to the onset of stress-related to a person's behavioral, psychological, and biological interactions concerning fellow workers and other work environments [15]. The researchers' analysis results show that most teachers at SMK Muhammadiyah still hold a bachelor's degree and only as many as 15 teachers who have a master's degree. The high risk of stress is also influenced by education in which the secondary education group, compared to tertiary education (bachelor and master), can occur because those with less education have limitations in coping patterns of the problems experienced. Hence, workers with higher education have better abilities and knowledge. Therefore, the impact on the ability to deal with life problems tends to be more able to overcome challenges, so the risk of experiencing stress is lower [15].

Work stress is caused by the environment, social situations, and physical demands that cause a person to get angry quickly, emotionally, and depressed. Stress that occurs to workers must be immediately addressed not to affect his work, physical and psychological condition [16]. One way to deal with stress conditions is to use coping strategies that are problem-centered and emotional-centered. This coping strategy is a way someone changes the reaction or response in dealing with problems to alleviate problems such as dealing with issues directly, looking for the source of the problem, and looking for help to solve the problem. The next 
coping strategy is a strategy that focuses on emotions that are done to reduce the impact caused by seeing the positive side of yourself when experiencing stress, avoiding problems, trying to put things following their position, and finally by involving things that are religious [17].

Another stress relief strategy is a strategy that focuses on eating patterns when stress occurs by maintaining a definite eating pattern that is eating calmly and sufficiently so that the body can accept and function properly to avoid health problems such as obesity. Sometimes a person has a habit of eating to cope with stressful conditions. It can be directed from sweet foods, which are foods that contain sugar, such as fruits. Sugar or something sweet can trigger endorphin release, which creates euphoria or feeling happy [18].

The data obtained from the Body Mass Index (BMI) found that most of the respondents' BMI was normal as many as 34 respondents $(54.0 \%)$. Total IMT affected by several things, including nutrition, diet, physical activity, socioeconomic status, level of education, level of knowledge, and the state of the environment. Nutrition intake affects a person's BMI, the more often a person eats, the more nutrients will be obtained. A person's education and knowledge about food also influence the food he consumes, which can affect one's nutrition and the good and bad of food for the body. The high socioeconomic status also affects a person's purchasing power to meet his nutritional needs so that it can change the size of one's BMI [19]. A person's diet will affect one's nutritional problems. Problems with poor nutrition due to the wrong food can also affect decreased physical fitness. The intended menu includes the frequency of meals, meal times, and consumption levels. Incorrect dietary habits such as consuming snacks and fast food can cause the body's nutritional needs not to be fulfilled due to the content of meals and fast food such as energy, high sodium, fat, and low in vitamins and minerals [20].

Nutritional status influences the occurrence of obesity. Nutritional status is the state of the body that is affected by certain nutrients due to food consumption. Adequacy of a person's dietary intake can be known through his nutritional status [21]. Nutritional status in adults is seen based on body weight and height using BMI values. There is a significant relationship between nutritional statuses, such as the frequency of eating fast food, breakfast habits, and obesity. That is because the body gets much dietary intake from fast food, which, if consuming fast food with excessive frequency, can cause the risk of obesity. This is because fast food is a type of fast food that is high in energy, high in sugar, high in fat and low in fiber [21].

Physical activity can also affect one's diet, regular physical activity will make fat oxidation increase, and appetite can be controlled [22]. Neighborhood and workplace can affect a person's BMI. The location of residence or workplace affects a person in choosing decisions about his health, for example, the area of the workplace is quite far away, lack of availability of time and place at work, so that affects the physical activity of the individual [13]. Stress can also affect a person's BMI. When stressed, the body will release the hormone cortisol. High levels of the hormone cortisol in the body can stimulate the body to release the hormones insulin, leptin, and neuropeptide (NPY) so that it can cause hunger in someone who is experiencing stress. It can trigger a person desirous of eating [7] The results of research regarding the relationship of stress with obesity that irregular eating patterns more cause the nutritional problems that arise in young adulthood [23]. This is caused by poor eating habits, a wrong understanding of nutrition, excessive preference for certain foods. Obesity to workers can be caused by high work pressure, and they cannot hold thoughts that result from work stress. Stress can affect a person's behavior and metabolism so that it can support the occurrence of obesity [24].

Stress can affect one's metabolism and eating behavior to support the occurrence of obesity [24]. This is caused by the release of the hormone cortisol in the body. High cortisol hormone can affect the function and distribution of fat tissue so that it can cause obesity, such as central obesity [10]. This can occur when stressed; one's body will release the hormone cortisol in the body. High levels of the hormone cortisol in the body when it is released, can stimulate the body to release the hormones insulin, leptin and neuropeptide (NPY), these hormones can trigger hunger, thus making a person eager to eat. The hypothalamus is the part of the brain that plays a role in regulating one's appetite. The hypothalamus in the lateral and ventromedial is the center of eating and the center of feeling full. The hormone ghrelin in the body can play a role in increasing one's appetite. The most ghrelin hormone is from the stomach. The hormone ghrelin can increase food intake and cause changes in fat reserves. The hormone ghrelin stimulates appetite by activating insulin, leptin, and neuropeptide (NPY). Conditions of stress, anxiety, and depression are triggers for the activation of these neurons [7].

The results showed that there was no relationship between job stress with obesity in Teacher at SMK Muhammadiyah. It showed that most teachers stress levels in the category of moderate stress. The research suggestion given is that the results of work stress research obtained in this study can be used as preliminary data for further research on nursing interventions that are appropriate for reducing work stress rates. The need for school policies to deal with stress on teachers so as not to increase the level of severe stress

\section{CONCLUSION}

The study results showed that most respondents were teachers of early adulthood (26-35) years old, male sex, with a long working period of more than three years. Most respondents are in moderate stress (mean $=31,13, \mathrm{SD}=$ 4, 75) with a healthy BMI category. The relationship between work stress and obesity in teachers is $p$ value $=0.157$. There was no significant relationship between work stress and obesity in teachers at Muhammadiyah Senior High School.

\section{ACKNOWLEDGMENT}

The researcher acknowledges Universitas Muhammadiyah Yogyakarta that provides funding for this research 


\section{REFERENCES}

[1] Budiwati, Hesti. " Identification of the stress sources of teachers and their effects on the performance of lecturers in STIE Widya Gama Lumajang." Widya Gama Luamajang. Wiga Economic Journal of Research. 2016; Vol.6 No.1.

[2] Karim, Nurlia. "Work stress influence to job performance p no employee café bamboo express manado. school of economics and business management department. Sam Ratulangi University Manado. Manado: EMBA Journal. 2013; Vol.1 No.4.

[3] Jundillah, Z .N., Ahmad, LOAI \& Saktiansyah, LOA. "Analysis of job stress genesis nurses in konawe islands. 2017". Faculty of Public Health. Halu Oleo University. Central Sulawesi: Scientific Journal of Public Health Students. 2017;Vol. 2 No.6.

[4] Health and Safety Executive. Focusing on work-related stress, musculoskeletal disorders and occupational lung disease. HSE Priced and Free Publications Can be Viewed Online or Ordered from www.hse.gov.uk. 2017.

[5] Satrio, Pramonos. "The effect of work shifts and job stress on the performance of salespeople at pt circleka indonesia utama, yogyakarta branch. management study program-department of management. Faculty of Economics. Yogyakarta State University. 2015.

[6] Putranto, sophisticated. "Factors affecting work stress: indigenous studies on javanese ethnic teachers". Journal of Social and Psychology, 2013;Vol.2 No.2.

[7] Purwanti, Putri, Ilmiawan, Wilson \& Rozalina. "Relationship between stress level and body mass index of fk untan pspd students". Journal of Health Vocations, 2017; Vol.3 No.2.

[8] Ilham, Muhammad. "Relationship between obesity and body image of students in SMA N 3 Banda Aceh". Medical Study Program. U Syiah Kuala Darrusalam University, Aceh . 2017.

[9] Riyanto, Agus, Megasari, Mona. "The relationship between eating habits and sports with more weight on stikes public health students Acmad Yani Cimahi". Kartika Health Journal, 2016;Vol.11 No.1.

[10] Khotibuddin, Muhammad. "The relationship between depression and eating behavior against weight loss in medical students". faculty of medicine and health sciences. Yogyakarta Muhammadiyah University. Yogyakarta: Mutiara Medika, 2017; Vol.17 No.1.

[11] Fitr, A . M. "Analysis of factors related to occurrence of job stress on bank employees (Study of BMT Bank Employees)." Semarang: Journal of Public Health, 2013; Vol. 2 No.1.
[12] Wu., \& Shih. "The effect of gender roles on perceived job stress". Journal of Human Resources and Adult Learning . 2010; Vol.6 No.2

[13] Purwati, S. " Menu planning for overweight patients ". Jakarta: SelfPublisher. 2011.

[14] Fahmi, S. "The effect of work stress and work conflict on employee morale in employees of PT. Omega Mas Pasuruan ". Journal of Modernization Economics , 2016;Vol. 12 No.3.

[15] Besral \& Widiantinni. "Determinants of stress in indonesian ministry of health employees". National Journal of Public Health , 2015;Vol. 9 No.3.

[16] Ananda, R . K. "The effect of job stress and workload on employee job satisfaction of PT. Surya Teknik Anugerah Samarinda". Psychology Study Program. August 17, 1945 Samarinda University . 2014.

[17] Sitepu, JM, Nasution, M. The influence of self concepts on coping stress in fai ums students. Intiqad Journal of Religion and Islamic Education. 2017; Vol. 9 No. 1

[18] Victoriana, Evany. " The design of weight control program b a and share individuals experiencing obesity" .Fakultas Psychology. Marantha Christian University, Bandung. 2012.

[19] Putra, Ermawati \& Amir. Relationship between body mass index (BMI) and menarche age in middle school 1 Padang Student

[20] Andalas health journal Vol 5. No.3. 2016

[21] Septiana. P, Nugroho. FA, and Wilujeng, CS. Consumption of junk food and fiber in overweight and obese young women. J urnal Medicine Brawijaya Vol 30. No. 1;2018; pp 61-67

[22] Kurdanti et al. Factors that influence the incidence of obesity in adolescents . Indonesian Clinical Nutrition Journal Vol 11, No. 4, 2015

[23] Hartyaningtyas \& Fatmah. Factors that influence the Body Mass Index (BMI) of Marsudirini High School Students in 2013.

[24] Faculty of Public Health. University of Indonesia

[25] Sacred, Y . P . " The relationship of nutritional status with stress levels in medical education students ". Faculty of Medicine. Syiah Kuala University . 2016

[26] Widiatinni, Winnie and Zarfiel Tafal. "Physical activity, stress, and obesity in civil servants". National Journal of Public Health 2014;Vol.8 No.7 